\title{
THE ROLE OF THE DEMOCRATIC AND REPUBLICAN PARTIES AS ORGANIZERS OF SHADOW INTEREST GROUPS
}

\author{
Jonathan R. Macey*
}

Political parties are one of the most poorly understood components of American political life. Neither political scientists nor economists have explained adequately what political parties are and what they do. Generally speaking, political scientists underestimate the significance of political parties, while economists mischaracterize the role that they play.

This article advances a new theory to explain the relationship between political parties and interest groups. Among the as yet unanswered questions that I resolve are: (1) why many politicians - both Republicans and Democrats - develop a reputation for "party loyalty" despite the parties' inability to employ any meaningful sanctions against politicians who deviate from the party line; (2) why candidates for public office run in contested primaries when running as an independent generally would be a less costly mechanism for getting on the ballot; (3) why the two major U.S. political parties continue to attract resources from contributors and to inspire loyalty among various groups despite an apparent decline in party strength as shown by split-ticket voting, contested primaries, and a growing lack of ideological cohesion within party platforms.

I argue that at times the costs of organizing into interest groups will outweigh the benefits for certain groups of individuals. Political parties enable these unorganized interest groups to find expression in the political process at relatively low cost. My model of the two major political parties depicts such parties as political brokerage firms. The objective of these intermediaries is to increase their value to the politicians and potential politicians who serve as their clients. The parties do this by serving as arbitrageurs who signal politicians of citizens' preferences and thereby inform politicians about how to obtain political support. This matching process lowers the transaction costs to

* Professor of Law, The University of Chicago. B.A. 1977, Harvard University; J.D. 1982, Yale University. - Ed. A nascent version of this paper was presented at a Faculty Seminar at Cornell Law School. I am grateful for comments received there and from Geoffrey P. Miller, Michael C. Munger, Andrew Rutten, Roy A. Schotland, and Cass R. Sunstein. The research for this article was supported by a grant from the John M. Olin Foundation. 
certain citizens of entering the political process. By expanding the set of individuals who think they can influence government, political parties enlarge the range of interests that can find expression through government action, and expand the aggregate political support available to politicians.

Current models of the political process view the world as divided into two groups: highly organized special interest groups on the one hand, and totally disorganized, atomistic voters on the other. ${ }^{1} \mathrm{My}$ model expands the set by adding an intermediate form of political organization - the shadow interest group. I introduce the concept of shadow interest groups to show that the world of politics does not divide neatly into highly organized interest groups and highly disaggregated voters. In fact, dozens of intermediate sorts of organizational forms fall between these two polar extremes. ${ }^{2}$ Shadow interest groups occupy a middle ground between true interest groups and individual voters. Shadow interest groups are different from true interest groups in that they lack formal organizational structure. Shadow interest groups are different from ordinary voters because, like members of formal interest groups, their policy preferences are almost exclusively tied to a particular set of issues. Such shadow interest groups do not organize into formal interest groups because the costs of organizing outweigh the benefits. ${ }^{3}$ Political parties serve the valuable role of

1. See, eg., Denzau \& Munger, Legislators and Interest Groups: How Unorganized Interests Get Represented, 80 AM. POL. SCI. REv. 89, 90-92 (1986); Tollison, Public Choice and Legislation, 74 VA. L. REV. 339, 363-64 (1988).

2. Mancur Olson, Douglas Keenan, and Paul Rubin have made important contributions to public choice literature by exploring the extent to which potential interest groups can affect the regulatory process. Olson developed the concept of latent interest groups, which are groups with similar interests that lack the system of selective sanctions and incentives necessary to become effective in the political marketplace. M. OLSON, THE LOGIC OF COLLECTIVE ACTION 48-52, 132-35 (1965). Keenan and Rubin observe that some interest groups, which currently have no members and no people who identify with them, would be able to coalesce into an effective political coalition if politicians were to take certain actions deleterious to their interests. Keenan and Rubin describe these groups as "shadow interest" groups. Keenan \& Rubin, Shadow Interest Groups and Safety Regulation, 8 INTL. REV. L. \& EcoN. 21-22 (1988). The description advanced by Keenan and Rubin and by Olson envisions groups that, because of various constraints and disincentives, are not currently organized into an effective political coalition. By contrast, the shadow interest group I describe is an active political force that provides political support to politicians in exchange for regulatory forbearance.

3. M. Olson, supra note 2, at 47-50; Keenan \& Rubin, supra note 2, at 22. As will be seen, some interest groups evolve into formal political coalitions while others remain shadow interest groups for two principal reasons. First, some interest groups face higher start-up costs than others. Some groups, like the labor unions and the American Bar Association, have independent reasons for galvanizing into a formal organizational structure. For these groups, the marginal costs of organizing into a formal interest group will be quite low. Other groups, like members of a particular religion or sexual orientation, lack any independent basis for formally organizing. Such groups are shadow interest groups because they exist independently of a formal organizational structure. Second, some interest groups will prefer shadow status to formal status because 
increasing the political effectiveness of members of shadow interest groups.

Political parties serve the needs of these quasi-interest groups in a variety of ways. ${ }^{4}$ First, political parties lower the information costs that shadow interest groups face when attempting to identify viable candidates whose policy preferences match their own. Second, because it is more costly for politicians to forge ties with shadow interest groups than with formally organized interest groups, political parties benefit politicians by providing a lower-cost alternative means of creating ties to these groups. In addition, political parties benefit politicians by providing them with information about the preferences of shadow interest groups. This information enables politicians to identify more precisely the opportunity costs associated with the passage of particular legislation.

My argument is not that political parties serve shadow interest groups exclusively and provide no services at all to organized interest groups. Rather, my argument is that the political parties' ability to serve organized interest groups has been declining steadily over time because such groups have gained direct access to politicians and no longer need political parties to serve as intermediaries. To survive, political parties have had to expand their traditional constituency to include shadow interest groups. Political parties do, however, provide one important service for both formal interest groups and shadow interest groups: they provide a mechanism by which politicians can make credible (bonded) promises to these groups.

Despite the increasing ability of formal interest groups to obtain direct access to politicians, political parties aid these groups by increasing the durability and reliability of the bargains they strike with politicians. It is well known that interest groups and politicians who wish to enact interest legislation face severe nonsimultaneity of performance problems. ${ }^{5}$ Political support generally is given by interest groups to politicians prior to the time when such groups need political favors from the politicians. Consequently, both politicians and interest groups constantly are searching for ways to improve the credibility

formally organized interest groups face the specter of rent extraction. See infra notes 69-71 and accompanying text for a more complete discussion of rent extraction.

4. I use the terms "quasi-interest group" and "shadow interest group" interchangeably. As Michael Munger quite correctly has observed, the term should be "interest quasi-group" not quasi-interest group, since what is "quasi" is not their interest but their status as a group. I persist in using the term quasi-interest group only because I think it less awkward.

5. Macey, Public Choice: The Theory of the Firm and the Theory of Market Exchange, 74 CORNELl L. REV. 43, 53 (1988). 
associated with the rent-seeking process. ${ }^{6}$ Political parties are one means for improving the reliability of interest group bargains. By developing a reputation for loyalty to a particular political party, a politician can make a credible commitment to interest groups. In this way political party affiliation serves a function similar to that played by ideological commitment, that is, increasing the credibility of candidates' preelection promises.

Perhaps the two most important observations one can make about American political parties are: (1) virtually no meaningful ideological issues divide the two major parties; and (2) despite this lack of ideological difference, certain groups, such as Jews and blacks, and of course the infamous "silent majority," tend to associate themselves disproportionately with one political party or the other. Increasingly, the efforts of political parties are being directed toward identifying issues that will enable them to attract and retain the support of such shadow interest groups. Political parties not only help the voters who are members of these shadow interest groups to identify the politicians they are likely to prefer, they also provide politicians with information about the nature of these groups and about their preference functions. It is the thesis of this article that political parties solve a variety of contracting problems that shadow interest groups face when they attempt to become involved in the political process. The political parties screen candidates for shadow interest groups in order to make sure that they are electable and reliable. After election, the parties facilitate the enforcement of politicians' promises to shadow interest groups, and they shield such interest groups from the costs associated with rent-extraction.

Until now, models of interest group behavior have treated all interest groups alike, regardless of whether they are formally organized (like the Teamsters or the American Bar Association) or not. Under my theory, political parties serve as the vehicle by which less formally organized interest groups make their views known. Other sorts of political organizations, like Political Action Committees (PACs), serve the interests of the formally organized interest groups, but political parties provide a unique service to shadow interest groups.

In Part I of this article, I explain and critique the role attributed to political parties by political scientists. Surprisingly, political scientists

6. Rent-seeking is an attempt to obtain economic "rents," which are payments for the use of an economic asset in excess of its market price, through government intervention in the market. A classic example of rent-seeking is an attempt by an industry group to obtain restrictions on foreign imports of the goods manufactured by its members. The increased profits obtained from such restrictions is economic "rent" from government regulation. 
agree about the function of political parties from both a positive as well as a normative perspective. On the positive side, political scientists believe that political parties are declining in importance. The dominant view is that political parties no longer play an important role in American political life. The debate on this issue, to the extent there is one, focuses on the magnitude of the decline rather than on its existence. On the normative side of the ledger, political scientists regard the decline of political parties as an unfortunate event. The decline is seen as a serious threat to democratic values, as is the decline of party organizations and party identification among voters.

I turn in Part II to the treatment of political parties under the economic theory of regulation. Scholars working in this genre take one of three approaches to political parties. One important school of thought ignores political parties altogether and formulates models of political behavior as though parties did not exist. Another school treats political parties as suppliers of brand names that provide voters with low cost sources of information about candidates. A final approach treats political parties as umbrella organizations for a variety of interest groups. Part II demonstrates that, while each of these accounts contains important kernels of truth, none provides a complete account of the role of political parties.

In Parts III and IV, I present my theory of political parties. Under my theory, political parties are not political organizations that attempt to influence government. Rather, the parties are viewed first as a unique form of political brokerage firm that reduce the transaction costs to certain individuals of organizing into effective political coalitions, and second as a substitute for ideology in signalling politicians' future behavior on issues of importance. In other words, political parties act as brokers between candidates for public office on the one hand and shadow and formal interest groups on the other.

In Part V, I make some preliminary observations about the normative implications of my theory before concluding in Part VI.

\section{The Political Scientists' Approach to Political Parties}

Political scientists are remarkably united in the view that political parties are declining in importance. ${ }^{7}$ The consensus dates from at least as far back as 1950, when the Committee on Political Parties of the

7. "In a world in which political scientists disagree on almost everything, there is a remarkable agreement among the political science profession on the proposition that the strength of American political parties has declined significantly over the past several decades." Orren, The Changing Styles of American Party Politics, in The FUTURe of AMERICAN PolitiCal ParTies: The Challenge of Governance 31 (J. Fleishman ed. 1982). 
American Political Science Association observed that changes in the social and economic structure of the United States required a focus on national issues that political parties were unable to provide. ${ }^{8}$ Cornelius P. Cotter and John F. Bibby have summarized the prevailing wisdom with the observation that

[p]olitical scientists, pushing the concept of electoral realignment to the limits of its logic and working from the methodological strength of survey and attitudinal research, have formulated and tested a theory of politics that leads them to conclude that American political parties are in steady decline and may verge upon extinction. The electorate's declining commitment to party, the apparent lessened interest of activists in party organization, and the salience of personality and issue over party loyalty are indicators of party decline. ${ }^{9}$

Echoing this view, Theodore Lowi has argued that political parties have become largely irrelevant and has expressed concern over the parties' continual drift toward the periphery of national politics. ${ }^{10}$ Professor Lowi has argued that President Eisenhower's nomination as the Republican party's candidate for the presidency and his election to that office in 1952 marked the beginning of the decline of party politics in two significant ways. First, it represented the first time that the candidate who was the favorite of the party machinery (Senator Robert Taft) failed to win the nomination. ${ }^{11}$ Second, Eisenhower's electoral victory over Adlai Stevenson marked the first time that a successful presidential campaign was organized and run independently of the party machinery. ${ }^{12}$ Similarly, Lowi points out that recent presidential candidates from both parties have been selected from outside the party structures, and split-ticket voting as well as contested primaries have been rising consistently for the previous fifty years, indicating the decreasing significance of party affiliations. ${ }^{13}$ And it seems clear that national political parties have been less influential in controlling presidential campaigns, dispensing federal patronage, and controlling presidential nominations than at any time in our history.

8. Committee on Political Parties, Toward a More Responsible Two-Party System, 44 AM. Pol. SCI. REv. 1, 3-4 (Supp. 1950).

9. Cotter \& Bibby, Institutional Development of Parties and the Thesis of Party Decline, 95 PoL. SCI. Q. 1 (1980). Cotter and Bibby argue that political parties are in decline when viewed from this perspective. But, consistent with the view espoused in this article, Cotter and Bibby find that the national parties are increasing in strength in terms of the discipline they are exerting over state and local organizations, their enforcement of rules, and their provision of organizational services and administrative activities. $I d$. at 1-2. (1985).

10. T. Lowi, The Personal President: Power Invested, Promise Unfulfilled 71

11. Id. at 71-73 (1984).

12. See id. at 71-72.

13. See id. at 73-79. 
In the same vein, in his classic work on the American Political Tradition, Richard Hofstader observed that "party differences have rarely been profound." Hofstader went on to note the "profound uniformity between Republican and Democratic principles."14

\section{A. The Survival of Political Parties}

In this section, I contend that political scientists mischaracterize the role played by political parties. I also argue that once the role played by political parties is properly understood, it is clear that their role is not declining, but merely evolving to serve a different set of voters.

Political scientists have failed to explain at least three salient facts about American political parties. First, despite political science pronouncements that parties are unimportant and powerless, the two major parties have survived and prospered. The Democratic and Republican parties have survived intact since the mid-nineteenth century, ${ }^{15}$ strongly suggesting that these parties are providing something of value to politicians and interest groups.

Second, political parties are able to raise and distribute increasingly large sums of money in campaigns, also suggesting that political parties are not on the decline. ${ }^{16}$ For example, between 1977 and 1984, the Republican party increased the amount of money raised in federal elections by a factor of three. The Democratic party increased the amount of money it raised by an even greater factor. ${ }^{17}$ Similarly, the total amount spent by the two major political parties in federal election contests is even greater than the amount of money spent by Political Action Committees (PACs) in such contests. ${ }^{18}$

Finally, the dominant view of political parties held by political

14. R. Hofstader, The American Political Tradition 231 (Vintage Books ed. 1974).

15. The Republican Party came into existence in 1854. Its birth can be traced to the KansasNebraska Act, which overturned the Missouri Compromise of 1820 and the Compromise of 1850 which had barred slavery in the territories. In opposition to this new legislation, antislavery groups coalesced into the Republican Party. CoNG. Q., GuIDE To U.S. Elections 179-84 (1975).

The Democratic Party came into existence around 1824 when the Jeffersonian, or Democratic-Republican Party broke apart and Andrew Jackson emerged as the leader of one of the resulting splinter factions. In 1830 , Jackson changed the name of his party from the DemocraticRepublican to the Democratic. Id. at 179-80.

16. See X. Kayden \& E. Mahe, The Party Goes On: The Persistence of the TwoPARTY SYSTEM IN THE UNTTED STATES 183 (1985) (noting the increased financial resources of political parties).

17. The actual increase was from $\$ 84.5$ million to $\$ 297.9$ million for the Republican party, and from $\$ 26.4$ million to $\$ 98.5$ million for the Democratic party. Federal Election Commn. Press Release, 2,4 (Dec. 5, 1985), reprinted in L. Epstein, Polttical PARTIEs IN THE AMERICAN MOLD 351 (1986).

18. L. EPSTEIN, supra note 17, at 354. 
scientists fails to explain why party membership remains a sine qua non for becoming elected to political office in the United States. After all, if political parties are powerless and irrelevant, as often is claimed, it is difficult to understand why candidates who attempt to run for political office without the support of one of the major parties are almost always unsuccessful.

Political scientists generally consider political parties unsuccessful because they view such parties as political organizations seeking influence over government. ${ }^{19}$ Under this view, political parties "seek to control the entire government by controlling its personnel." 20 In other words, political scientists view political parties as organizations with independent policy agendas that attempt to obtain substantive policy outcomes.

This model of political parties is significantly different from, and inferior to, the economic model of political parties developed initially by Anthony Downs. ${ }^{21}$ The economic model views parties as interested in getting candidates elected, not as interested in influencing policy outcomes. The clients of the political parties are of course interested in influencing outcomes, but the parties themselves simply are conduits through which the policy preferences of these clients can find expression.

It is the political scientists' misunderstanding of the nature of political parties that has led them to conclude that such parties are declining in influence. Their tests of the importance of political parties measure the extent to which the parties are successful in controlling government by controlling the electorate. Thus, for example, political scientists point to the dramatic increase in so-called split-ticket voting $^{22}$ as evidence of the decline of political parties. ${ }^{23}$

Ticket splitting undoubtedly is on the increase. ${ }^{24}$ The proportion of voters reporting that they have voted for different parties in presidential elections rose from $29 \%$ to $57 \%$ between 1920 and 1976. In addition, ticket splitting between presidential and House candidates

19. T. LOWI, INCOMPLETE CONQUEST: GOVERNING AMERICA 195 (2d ed. 1981).

20. Id.

21. A. Downs, AN ECONOMIC THEORY OF DEMOCRACY (1957).

22. In split-ticket voting, voters divide their votes among candidates of different parties running for various offices in the same election.

23. M. Wattenberg, The Decline of Political Parties, 1952-1984, at 23 (1984).

24. T. LowI, supra note 19, at 199 ("More American voters . . split their tickets by voting for candidates of one party for certain offices and then crossing over to vote for one or more candidates of the opposing party.") (emphasis omitted); D. MCKAY, AMERICAN Politics AND SOCIETY 91 (1985) (ticket splitting on the rise due to weaker party identification, which produces a "more fickle electorate"). 
increased from $12 \%$ to $34 \%$ during this period. Similarly, ticket splitting between House and Senate candidates rose from $9 \%$ to $31 \%$, and the proportion of voters splitting their tickets in local elections rose from $27 \%$ to $59 \% .{ }^{25}$ Thus, contrary to common assumption, the increase in ticket splitting is not simply a result of the fact that the Democratic party has nominated presidential candidates that are more liberal than the population as a whole. As Wattenberg has observed, "Ticket-splitting has assumed massive proportions compared to the rate just two decades ago, and only a small minority of the electorate now believes that one should vote strictly on the basis of party labels."26

Political scientists have pointed to the increasing number of contested primaries as further evidence of the decline of political parties. Contested primaries are seen as evidence of the decline of political parties because "a contested nomination is costly. Money that is spent on campaigning in the primaries is no longer available to spend in the general election against the opponent nominated by the other party."27

Still, like the evidence that political campaigns are being organized from outside the party organization, ${ }^{28}$ and the evidence that presidential candidates are being selected from outside the formal party structure, ${ }^{29}$ the statistics about ticket splitting and contested primaries provide evidence of party decline only if one defines political parties as organizations that attempt to influence government. If, on the other hand, one defines political parties as organizations that attempt to galvanize shadow interest groups into effective political coalitions, then one needs a different yardstick to measure the success or failure of political parties.

Split-ticket voting reflects the fact that members of shadow interest groups often identify more strongly with the candidates for office at one level of government than with the candidates for office at another level of government. Political parties serve as intermediaries between shadow interest groups and politicians. This service may be more in demand at some levels of government than at others.

Most voters will identify with shadow interest groups with regard to some issues, and with formally organized interest groups with regard to other issues. These same voters may not identify with either sort of group with regard to other issues. Rational, self-interested vot-

25. M. WATTENBERG, supra note 23 , at 20.

26. Id. at 23.

27. T. LowI, supra note 19, at 206.

28. T. LowI, supra note 10 , at 71-73.

29. Id. 
ers will cast their votes so as to increase their overall welfare. This will lead to voting along party lines for candidates running for political offices that can further the goals of a particular shadow interest group, and to voting that does not reflect party loyalty with respect to candidates running for offices that wield particular influences over goals important to a special interest group. For example, an affluent voter who supports U.S. aid to Israel consistently may vote for Democratic candidates to Congress because that party has been a more consistent supporter of aid to Israel. But the same voter also may consistently vote for the Republican candidate for President since the Republican is more likely to veto congressional tax increases.

This voting pattern is consistent along party lines, but it produces split-ticket voting. It also produces the voting pattern that allows the voter to maximize the personal benefits associated with his vote. The voter anticipates that the benefits to him from the President's veto of new taxes will be greater than the costs associated with the President's association with a political party that is relatively lukewarm on support to Israel. Similarly, the voter anticipates that having an additional Democrat in Congress will not affect the probabilities of new taxes as much as it will affect support for Israel.

Political scientists also point to the decline in party membership, ${ }^{30}$ and the lack of ideological cohesion within parties, ${ }^{31}$ as evidence of the decline of political parties. If political parties are viewed as organizations seeking to represent the views of completely disorganized, atomistic voters, then these would be meaningful signals of party decline. Lack of ideological cohesion would render the parties useless to individual voters seeking to use the parties as low-cost signaling devices over a range of issues. The decline in party membership does demonstrate that the parties do not serve the interests of individual voters.

If, on the other hand, parties are viewed as indifferent to the preferences of individual voters, but highly attuned to the preferences of shadow interest groups, these statistics take on a new meaning. Unlike individual voters, members of shadow interest groups do not care about party cohesion. They care about how particular candidates stand on particular issues, and are indifferent to the candidates' stance

30. D. MCKAY, supra note 24, at 91 (showing that party identification, defined as the attachment that individual voters have to particular parties, has been weakening steadily over the previous 30 years); N. Nie, S. Verba \& J. PetrociK, The Changing AMERICAN Voter 57 (1979) (arguing that voters hostile or indifferent to the dominant political parties had replaced loyal party faithful by the 1970s).

31. G. Pomper, Elections in America: Control and Influence in Democratic Politics 168-73 (2d ed. 1980) (On most issues, American parties do not offer clearly different choices. Both parties tend to support programs of proved popularity.). 
on other issues. These groups do not care about ideological coherence. Consequently, ideological consistency is a cost to political parties because it forces them to take unpopular stands on issues in order to prove their consistency. Thus, the lack of ideological coherence among the political parties merely illustrates that such parties do not serve the interests of the people at large. But this lack of ideological coherence does not indicate that the parties serve no purpose in the political process.

\section{B. The Normative Twist}

If one abandons the view that political parties are organizations that attempt to influence government, and substitutes for it the view that political parties are political organizations that serve the interests of individual clients, it is harder to demonstrate that political parties are on the decline. As noted above, the parties are flourishing financially, and the ability of politicians to win elections without their support is virtually nonexistent.

Not only do political scientists take the view that political parties are unimportant as a descriptive matter, they also take the view that their lack of power and influence is a serious problem as a normative matter. ${ }^{32}$ An important school of thought within political science considers the absence of strong political parties in the United States to be a "serious weakness of the American political system . . . and interprets the decline of party organization and party identification as a potential crisis in the current American political process." 33

Political scientists see parties as a "good thing" because they are "large scale institutions that attract diffuse majority support and overcome some of the collective action problems [inherent] in ... government administration." 34 The premise underlying this normative theory of political parties is that political parties are centralized institutions that represent society as a whole rather than narrow interest group constituencies. As organizations designed to effect the "mobilization of majorities," political parties counteract the negative tendencies of nar-

32. See Fitts, The Vices of Virtue: A Political Party Perspective on Civic Virtue Reforms of the Legislative Process, 136 U. PA. L. REv. 1567, 1603-17 (1988).

33. Id. at 1603-04; see also W. CrottT, AMERICAN Parties IN DeCLINE 281 (1984); see generally The AMERICAN Party Systems: Stages of Political Development (W. Chambers \& W. Burnham eds. 1967); N. NiE, S. Verba \& J. Petrocik, supra note 30, at 73; D. Price, Bringing Back the Parties 105-07 (1984); Sundquist, Whither the American Party System?, 88 PoL. SCI. Q. 559, 576-79 (1973).

34. Fitts, Look Before You Leap, Some Cautionary Notes on Civic Republicanism, 97 YALE L.J. 1651, 1656-57 (1988). 
row partisan politics. ${ }^{35}$ In addition, democracies with strong and responsible political parties are seen as less likely to be swayed by particular narrow special-interest groups because "the party structure and the traditional party identification by the electorate can presumably permit leaders of the party to surmount the narrow interests of the electorate on particular issues and more often adopt solutions that inure to the overall benefit of the society." 36

This analysis of political parties seems suspect for a number of reasons. First, no evidence suggests that the preferences of the majority are less refiected in the public policies of the United States, where political parties are weak, than in the public policies of democracies such as the United Kingdom, where political parties are considered to be strong. ${ }^{37}$

Second, it seems highly doubtful that unorganized private citizens, who cannot galvanize into effective political coalitions for the purposes of attaining legislation from their elected representatives, will be more successful at making themselves heard by political parties. The idea that members of the House of Representatives serve narrow constituencies, while representatives of political parties serve broader constituencies is dubious. Strong political parties would not transform a seat in the House of Representatives into a national office. As long as members of the House are elected by particular districts, they will continue to focus on interests that concern their constituents. ${ }^{38}$ Attempts by political parties to nominate candidates with views that run counter to those of their constituents would fail.

Of course, members of the House can improve their constituents' welfare by exhibiting strong party loyalty with regard to issues that do not affect their constituents. By displaying party loyalty, members of the House impress the party leadership, and thereby move up in the party hierarchy and obtain more important committee assignments, enabling the politician to provide still more benefits to his constituents in the future. The long-run gains to a particular politician's constituents from having a representative who is an influential member of an important committee may be so high that it is in the interests of that politician to conform to the preferences of the existing party leader-

35. A. Ranney, The Doctrine of Responsible Party Government 10-11 (1962); E. SCHATTSCHNEIDER, PARTY GOVERNMENT 208 (1942).

36. Fitts, supra note 32 , at 1607.

37. Cf. Page \& Shapiro, Effects of Public Opinion on Policy, 77 AM. PoL. ScI. Rev. 175 (1983) (public opinion is often a proximate cause of policy in the United States).

38. Of course, the term "constituent" may be broadly defined to include not only a politician's geographic area, but also to include those groups to whom the politician supplies services and resources. See Denzau \& Munger, supra note 1, at 101-03. 
ship, even though doing so is against the short-run interests of certain constituents.

Finally, and most fundamentally, the argument that political parties would represent society as a whole rather than narrow self-interested constituencies is flawed because it is based on the false premise that political parties are national, rather than local in orientation and focus. In fact, political parties in the United States are loose amalgamations of very localized committees. As Professor Lowi has observed:

The most important levels of real party organization have been the state, the county, and, in larger cities, the assembly district or ward. And since the elected party committees are large, party rules usually provide for a smaller executive (or central) committee to make most of the actual decisions. ... .

Party organizations in the United States therefore turn out to be little more than layerings of district committees with overlapping boundaries and interlocking memberships. Most of the parties' regular workers are drawn from these large committees. There have been a few party leaders in the history of the United States whose power to coordinate districts and committees was extremely effective. However, in recent years, if there is any coordination at all, it is likely to come from the cooperation of two or more party levels whose overlapping boundaries give them a common candidate for a major office. ${ }^{39}$

Political parties are loosely organized, multilayered organizations. The premise that they are centralized institutions that might serve to aggregate the interests of a national constituency is flawed because it is based on a false assumption about the very nature of the political parties. The parties are local, not national, political organizations, that occasionally unite nationally for certain purposes, such as confirming presidential nominees who, in fact, have been preselected in local caucuses and primaries.

\section{The Economists' Approach to Political Parties}

The role of political parties is as poorly understood among economists as it is among political scientists. Despite its general success in explaining other aspects of American political life, the economic theory of regulation contains no role for political parties. As Matt Lindsay and Michael Maloney have observed, "The function of political parties in democratic government has to date resisted successful incorporation into empirical models of politics. No economic theory of gov-

39. T. LowI, supra note 19, at 196-97 (emphasis omitted). 
ernment has a truly satisfactory role for these institutions."40

To economists, as well as to some political scientists, party affiliations serve as brand names for politicians; party affiliations are "cheap sources of information about which candidates are likely to best serve the interests of voters or contributors." ${ }^{11}$ Alternatively, economists sometimes describe political parties as umbrella organizations that service the common political goals of various interest groups. Under this view, the Democrats represent one set of interest groups, and the Republicans represent another. Neither explanation is convincing.

Perhaps the most common approach among economists is to ignore political parties. In modeling the political process, economists often disregard the role of political parties almost entirely. Congress is viewed as a firm organized to supply legislation to special interest groups in an efficient manner. At the heart of this approach is the committee system, which facilitates the contracting process among members of Congress, thereby assuring that the legislative deals that are passed will be stable over time. ${ }^{42}$

\section{A. The Missing Party: Congress as a Firm}

The economic theory of legislation applies game theory and microeconomic analysis to the production of law by legislatures, regulatory agencies and courts. An important branch of this theory portrays members of Congress as political brokers who seek to maximize political support by matching "those who want a law or transfer the most [as expressed by willingness to pay] with those who object the least."43 These politicians/brokers often play active roles in identifying those interest groups best able to supply political support for particular issues, and in drafting legislation in such a way that the payers will be unaware that they are subsidizing wealth transfers. ${ }^{44}$ In addition, "politicians can be expected to organize their own interest groups... in order to ameliorate the organizational costs and the free-rider problems that confront individuals who seek to form groups capable of (1988).

40. Lindsay \& Maloney, Party Politics and the Price of Payola, 26 Econ. INQuIRY 203

41. Peltzman, Constituent Interest and Congressional Voting, 27 J.L. \& EcoN. 181, 197 (1984).

42. Weingast \& Marshall, The Industrial Organization of Congress: Or Why Legislatures, Like Firms, Are Not Organized as Markets, 96 J. Pol. Econ. 132, 143-44 (1988).

43. Tollison, supra note 1 , at 343.

44. Macey, supra note 5, at 51; see also Macey, Promoting Public-Regarding Legislation Through Statutory Interpretation: An Interest Group Model, 86 CoLUM. L. REv. 223, 232-33 (1986) (explaining how special-interest legislation that effectuates wealth transfers but is disguised as having a public purpose is less costly politically than legislation that simply effectuates a naked wealth transfer to a particular group). 
obtaining governmental wealth transfers." 45

Political parties play virtually no role in this model of the political process. Individual legislators, without regard to party affiliation, are viewed as members of a single organization - Congress - which helps such legislators extract political support from interest groups more effectively. In particular, as Barry Weingast and William Marshall have observed, the theory of the firm can be employed to explain how politicians use the internal organizational structure of Congress to solve the enforcement problems that confront political supportmaximizing legislators who wish to obtain the political support from interest groups that is necessary for their survival. ${ }^{46}$ Members of Congress who wish to obtain passage of legislation must obtain the support of their peers. This generally will be done by logrolling, the common legislative process of giving support on one issue in exchange for receiving support on another issue. But politicians who seek to make deals with one another face severe enforcement problems because performance of logrolling agreements is not simultaneous. ${ }^{47}$ The economic theory of regulation shows that the organization of Congress is specifically designed to solve these sorts of contracting problems in order to maximize the political support that individual members can obtain. ${ }^{48}$ In particular, the committee system within Congress, where legislators retain control over the committees responsible for creating the laws that benefit their own constituencies, solves the nonsimultaneity of performance problem by restricting access to the agenda and therefore preventing ex post reneging. 49

Note, however, that political parties play no role in this model. The model posits only two classes of citizens: interest groups who demand and receive wealth transfers, and voters who provide the resources for such transfers through their fiscal support of transfer programs that benefit interest groups. Yet, as explained below, politicians can expand the scope of their political support by working through political parties to establish contacts with shadow interest groups. Unlike formally constituted interest groups, these quasi-interest groups lack direct access to legislators. These groups use political parties as intermediaries who broker the deals they make with politicians. Once elected, politicians honor the campaign promises made to these groups because the organizational structure of Congress makes it

45. Macey, supra note 5, at 51-52.

46. Weingast \& Marshall, supra note 42 , at $142-44$.

47. Id. at $140-44$.

48. Id. at 142 .

49. Id. at 144 . 
costly for them to renege. In other words, the organizational structure of Congress enables politicians to make credible promises that they will honor their commitments both to special interest groups and to shadow interest groups. The political parties are an important conduit through which the preferences of shadow interest groups are revealed to the politicians. Thus, when determining the political costs and benefits of a particular action, political parties are an important source of information to politicians.

\section{B. The Label Theory of Political Parties}

The label theory of political parties posits that party labels provide voters at least with some information, which the voters can receive without expending time or money..$^{50}$ This theory has a surface plausibility. Voters need a mechanism for economizing on information about their elected representatives. Voters have poor incentives to expend resources to become well-informed about their representatives. This is because voters are making collective decisions that are subject to the classic free-rider problems identified by Mancur Olson: individual voters cannot capture the full benefits of any gains they might obtain from becoming well-informed about the political process. ${ }^{51}$

The label theory is not particularly well specified. For example, James Kau, Paul Rubin, Joseph Kalt, and Martin Zupan suggest that party affiliation sends a low cost signal to voters about the ideological orientation of a particular party member. ${ }^{52}$ This label, it is argued, serves as a mechanism by which one can predict how politicians will vote on issues that do not matter very much to their constituents. In light of the lack of ideological cohesion among the parties, the label theory is not a particularly convincing explanation for the role of political parties. ${ }^{53}$ It is clear that "both major parties contain liberal and conservative wings which give expression to these tastes by voting together whenever ideology dictates in spite of party affiliation."s4 Thus a particular politician's party affiliation is not, in and of itself, a useful signal of the politician's ideological stance.

Sam Peltzman, on the other hand, takes the more plausible view (1984).

50. Peltzman, Constituent Interest and Congressional Voting, 27 J.L. \& EcoN. 181, 197

51. M. Olson, supra note 2, at 48.

52. Kau \& Rubin, Self-Interest, Ideology, and Logrolling in Congressional Voting, 22 J.L. \& ECON. 365 (1979); Kalt \& Zupan, Capture and Ideology in the Economic Theory of Politics, 74 AM. ECON. REV. 279, 284-85 (1984).

53. See supra notes 30-31 and accompanying text (discussing the lack of ideological cohesion among parties).

54. Lindsay \& Maloney, supra note 40, at 203. 
that party labels signal voters about the positions favored by particular candidates on particular issues, regardless of ideology. The problem with this approach is that politicians can identify themselves politically in other, better ways. Organizations such as Common Cause, or Americans for Democratic Action, are a better predictor than party affiliation of the positions favored by particular candidates on particular issues. Indeed, Peltzman's own data show that party membership is not a fundamental source of voting patterns for politicians. ${ }^{55}$ And, while candidate endorsements by organizations like Common Cause are not generally known, they are known to shadow interest groups and to interested individuals.

\section{The Umbrella Theory}

Another approach to political parties, which might best be characterized as the "umbrella theory," posits that political parties serve as a "banner under which economic groups within each constituency promote their common interests." 56 This theory is problematic, however, because political parties do not represent existing, well-organized interest groups. As Lindsay and Maloney have observed, "[I]t is far from clear which party represents the milk producers, the American Medical Association, the sugar refiners, the truckers, the suppliers of military hardware, banks and government bureaucrats." 57 These sorts of interest groups simply do not need the organized political parties. They can obtain direct access to particular candidates, and can monitor and enforce the bargains they strike with the politicians they support. Put differently, "if membership in a party merely reflects constituency interests, then there is no role for parties; they perform no economic function." 58

Thus, like the political scientists, the economists have been only partially successful at explaining the role played by political parties in American political life. The following section develops my theory of political parties, which posits that political parties cater to the needs of quasi-interest groups. Quasi-interest groups resemble formal interest groups in that they are narrowly focused around particular issues. Yet, they lack the organizational structure of firms, and therefore need political parties to facilitate the process of contracting with interest groups to exchange political support for political influence.

55. Peltzman, supra note 50, at 197.

56. Lindsay \& Maloney, supra note 40 , at 204.

57. Id.

58. Id. (emphasis in original). 


\section{Shadow Interest Groups and Political Parties}

Shadow interest groups occupy a middle ground between highly disaggregated individuals (a group sometimes referred to as "consumers at large") and highly organized special interest groups. Shadow interest groups differ from disaggregated individuals who are unable "to exercise any cogent influence over government decisions affecting them." 59 At the same time, shadow interest groups differ from real interest groups because they are not organized as firms, and therefore lack the ability to communicate among themselves and coordinate their actions in a meaningful way.

Although shadow interest groups seek to influence policy outcomes in certain areas, the costs to them of organizing into formal interest groups generally are higher than the benefits that accrue from achieving a formal organizational structure. Political parties enable these shadow interest groups to achieve some of the benefits available to formal interest groups despite their lack of a formal organizational structure.

This Part begins by explaining why shadow interest groups do not organize into formal interest groups. Section III.B then describes the relationship between the political parties and the shadow interest groups for whom they serve as intermediaries. I conclude this Part by showing the relationship between the theory of political parties contained in this article and the existing theories of political parties. I argue that the best explanation of the modern role of political parties is as organizers of shadow interest groups.

\section{A. Shadow Interest Groups and Formal Interest Groups}

Shadow interest groups do not form into formal interest groups for two reasons. First, the marginal costs of organizing into a formal interest group are significantly greater for shadow interest groups than for formal interest groups which have already been created for some other purpose. As such, it is more difficult for shadow interest groups to overcome the collective action problems of free riding and rational ignorance than it is for other groups. ${ }^{60}$

Second, it is costly for a shadow interest group to evolve into a formal interest group because politicians can look to the formal interest group as a source of transferable surplus. In other words, being

59. A. Downs, supra note 21 , at 255.

60. See generally M. Olson, The Rise AND Decline of Nations 36-74 (1982) (highlighting the problem faced by interest groups that must bear the entire cost of social improvements they prompt, while receiving only a small portion of the benefit). 
organized into a formal interest group is not unambiguously advantageous for the group so organized. In fact, certain groups will find that becoming organized into a formal interest group presents the danger that any gains they obtain will be transferred away by regulators. Remaining a shadow interest group will be the optimal strategy for these groups.

\section{The Marginal Costs of Organization}

The interest group theory of government is based on the premise that different groups face different information and transaction costs which allow some groups to organize and acquire information more cheaply than others. According to traditional public choice theory, politicians have an incentive to search for issues that transfer wealth to easily identifiable groups from disaggregated individuals. Because these disaggregated individuals face high transaction and information costs, they are not likely to discover the effects of the issue on their personal wealth. ${ }^{61}$

Politicians can gain political support at low cost by supporting this sort of legislation since the beneficiaries will pay to obtain passage of the legislation, while the interests that are harmed cannot impose meaningful political costs on the politicians. Well-organized interest groups enjoy the benefits of the wealth transfers generated by the political process, while individual voters bear the costs of these transfers.

Organizing an interest group to engage in the collective action necessary to obtain wealth transfers is both time-consuming and costly. Organization costs for interest groups are like start-up costs for firms generally. Once these costs are borne, they do not affect marginal costs. ${ }^{62}$ Thus once a group is formed - even if it was formed for reasons unrelated to lobbying - that group

will have a comparative advantage in seeking transfers and will therefore be more successful in procuring transfers as a result. This is simply a point about jointness in production. Some groups will be able to produce political lobbying as a by-product of performing some other function, thereby avoiding start-up costs for lobbying. There are many examples of such groups in the economy, among which are labor unions, trade associations, corporations, and the like. ${ }^{63}$

Thus formal interest groups are most likely to be those groups for whom the initial costs of organization are sunk. For these groups, the

61. Macey, supra note 44 , at 229-30.

62. R. MCCORMick \& R. Tollison, Politicians, Legislation and the ECONOMY 17 (1981).

63. Id. (citation omitted). 
marginal cost of using the preexisting organizational form for lobbying purposes will be low.

Clearly, however, groups other than those already organized desire access to the political process. Certain ethnic and religious groups, for example, are not formally organized into organizations capable of mounting meaningful political campaigns. Yet people who identify closely with these groups represent a valuable source of political support to politicians. The problem faced by the politicians is how to contract with these groups; these groups lack a formal organizational structure, and thus a readily identifiable leadership with whom politicians can contract.

In addition, the members of shadow interest groups seek to identify politicians who will advance their interests once elected. In this effort, shadow interest group members face a number of problems similar to the collective action problems faced by individual voters who wish to influence the political process. First, members of shadow interest groups must identify politicians who, if elected, are willing to act on their behalf. Next, they must determine if such politicians are viable (i.e., electable) political candidates, often a difficult process. Finally, they must monitor the activities of these candidates once they are elected in order to determine whether they in fact are acting consistently with the welfare of the shadow interest groups that supported them in the election.

Political parties can solve all of these problems for shadow interest groups and the politicians who wish to deal with them. The primary and caucus process, by which the parties choose political candidates, serves the valuable function of identifying candidates who are viable. In addition, political parties often will actively recruit potential candidates whom they think are electable. ${ }^{64}$ In this sense, the political parties do serve as brand names. While a political party's nomination does not contain concrete information about a candidate's ideological orientation, like brand names generally, a party's nomination signals shadow interest groups that a particular candidate is electable. This adaptation of the label theory explains why candidates for political office expend the considerable resources necessary to obtain a party's nomination in a contested primary, even though it is likely cheaper to get on the ballot by obtaining the signatures necessary under state law to qualify as an independent. 65 Thus, the contested primary and con-

64. See, e.g., Apple, 1990 Vote Will Test Power of G.O.P. in the Sun Belt, N.Y. Times, Feb. 25, 1990, at 26, col. 4 ("The Republicans have fared better than the Democrats in recruiting candidates for the big Senate races.").

65. U.S. CoNST. art. I, $\S 4$, cl. 1 delegates to the states the power to set the time, place, and 
comitant party endorsement provide a signal to shadow interest groups about which politicians are viable (electable) candidates in a general election. Independents lack this advantage. Those who win a party's nomination can obtain political support from individual members of shadow interest groups who now have the assurance that the candidate has a good chance of winning.

Finally, and perhaps most important, political parties are "exerting greater discipline over their respective state and local organizations and influencing those organizations through the services they provide." 66 In this way the parties can enforce the bargains they have struck with shadow interest groups by monitoring the activities of the individual elected officials and controlling the flow of funds to individual politicians. This enables the parties to enforce the promises made to shadow interest groups.

Political parties can be trusted to keep their bargains with shadow interest groups because the parties are stable, long-standing organizations, with stronger incentives than individual politicians to maintain reputations for keeping deals with shadow interest groups. This pattern of repeat dealing with special interest groups serves to make political parties' commitments credible.

This pattern of repeat dealing also makes the ties between shadow interest groups and political parties extremely durable. Perhaps the most striking example of the durability of the bond between shadow interest groups and political parties can be seen in the voting patterns of Jewish voters. As Lucy Dawidowicz trenchantly has observed:

[This pattern is] almost exactly the reverse of the national trend. That is while almost 60 percent of Americans voted for President Reagan, more than 60 percent of Jews voted for Walter Mondale (in the 1984 presidential election). The lopsided Jewish voting pattern resembled that of blacks, the unemployed, and persons in households earning under $\$ 10,000$ a year even though Jews in no way resemble those groups or

manner of holding elections. Generally speaking, it is easier for a candidate with the endorsement of one of the two major political parties to get on the ballot in a particular state. In New York, for example, independently nominated candidates for Congress must obtain 3500 signatures in order to secure a place on the ballot, while candidates with the endorsement of one of the two parties need only 1250 . Similarly, candidates for the state senate who are not affiliated with either major party must obtain 3000 signatures, while candidates with the support of the Republicans or the Democrats need only 1000 signatures. T. LOWI \& B. GINSBURG, AMERICAN GovERNMENT, FREEDOM AND POWER 508 (1990).

While it is costlier for candidates to obtain the additional signatures necessary to win a place on the ballot of a major party, it is extremely unlikely that the additional costs of obtaining these signatures is as high as the costs of mounting a successful campaign to win a contested primary. Garnering the extra signatures requires recruiting or paying additional solicitors; a contested primary frequently involves print, radio, or television advertising in addition to a campaigning schedule.

66. Cotter \& Bibby, supra note 9 , at 2. 
share their social and political interests. ${ }^{67}$

The reason that Jews have not realigned their voting patterns so as to give expression to the full range of their social, political and economic concerns is that they have a long-standing relationship with the Democratic party, and it would be costly to break that tie. Thus despite the fact that the Democratic party supports many policies, such as wealth redistribution and employment quotas, that are anathema to many Jews, ${ }^{68}$ the Jewish vote has been remarkably loyal to the Democrats.

\section{Rent Extraction and Shadow Interest Groups}

The relationship between a political party and a shadow interest group can be likened to the relationship between two firms in a long term, relational contract. Politicians searching for political support from organized interest groups can obtain such support in one of two ways. First, they can promise a particular group that they will press for regulations favorable to those groups. This process is known as "rent creation," and the groups that benefit from the process are "rent seekers."69 By this process of rent creation, special interest groups are thought to benefit from the regulatory process. As Fred McChesney has pointed out, however, politicians are capable not only of creating rents for interest groups, they also are capable of extracting rents by threatening to regulate in ways that will be costly to those groups. ${ }^{70}$ This extraction takes place because specific and expropriable capital is an inevitable by-product of the economic activities of firms, including organized interest groups. Over time these firms and groups invest in resources that have particular applications to certain uses. Politicians, knowing that the owners of these customized resources will suffer losses if the resources are not used for their intended purposes, can threaten to regulate in ways that will expropriate the specific and expropriable capital of these interest groups unless side payments are made for regulatory forbearance. For example, advertising creates a reservoir of good will for a product or service that enables firms to charge higher prices for those products and services. After a firm makes an investment in advertising, politicians can threaten to appro29.

67. Dawidowicz, Politics, the Jews and the 84 Election, 73 COMMENTARY, Feb. 1985, at 25,

68. See id. at 29-30.

69. McChesney, Rent Extraction and Rent Creation in the Economic Theory of Regulation, 16 J. LEgal STud. 101 (1987); see also Becker, A Theory of Competition Among Pressure Groups for Political Influence, 98 Q.J. EcoN. 371 (1983); Peltzman, Toward a More General Theory of Regulation, 19 J.L. \& ECON. 211 (1976); Stigler, The Theory of Economic Regulation, 2 BeLL J. ECON. MGMT. SCI. 3 (1971).

70. McChesney, supra note 69 , at 103. 
priate this investment by imposing price ceilings or by imposing minimum quality standards on all firms.

Being organized into a special interest group lowers the politicians' transactions costs of transferring the organized group's own surplus. ${ }^{71}$ Consequently, a second reason why groups that are unified around a particular interest may not choose to organize into formal coalitions is because they face the possibility of rent extraction if they do so. The political parties permit shadow interest groups to obtain gains by trading political support for preferential treatment by politicians while avoiding the specter of rent extraction.

\section{B. Political Parties and Shadow Interest Groups}

Political parties serve as intermediaries between shadow interest groups and politicians. Political parties convey to politicians information about the policy preferences of shadow interest groups. They also help politicians in their appeals to these groups by establishing mailing lists, donor lists and other contact points with group members.

Politicians need political parties to serve in the role of intermediaries because it is difficult for politicians to forge their own relationships with shadow interest groups. Because shadow interest groups lack a formal organizational structure, it is costly for politicians to identify and communicate with the individual members. But, unlike politicians, political parties develop longstanding ties to these groups that permit such groups to identify with the politicians nominated by the party.

In addition, and perhaps most important, the political parties enable politicians to enter into relational contracts with members of shadow interest groups. ${ }^{72}$ These relational contracts are "highly interactive ... arrangements [where] a complete contingent contract may not be ... feasible."73 The enforcement problems that might otherwise be associated with an open-ended and unspecified contractual arrangement are mitigated by the pattern of repeat dealing between shadow interest groups and political parties. This pattern of repeat dealing makes it possible for a shadow interest group to trust a particular party, despite the fact that they might not trust the individual politicians within the party. It is not surprising that the major political parties consistently have taken positions that seem to align them with the shadow interest groups with whom they are associated:

71. McChesney, Transferable Surplus and Interest-Group Organization in a Coasian Model of Regulation, 20 J. LEGAL STUD. 1 (forthcoming Jan. 1991).

72. Goetz \& Scott, Principles of Relational Contracts, 67 VA. L. REv. 1089 (1981).

73. Id. at 1090 . 
[T]he national feadership of the Republican party supports increased military spending, cuts in social programs, tax relief for middle- and upper-income voters, tax incentives to business, and the "social agenda" backed by members of conservative religious denominations. The national Democratic leadership, on the other hand, supports expanded social welfare spending, cuts in military spending, increased regulation of business, and a variety of consumer and environmental programs. These differences reflect ... differences in the core constituencies to which the parties seek to appeal. ${ }^{74}$

On the basis of the above description, one might argue that there is no meaningful distinction between the heterogenous, unorganized group known as voters, on the one hand, and shadow interest groups on the other. Unlike members of shadow interest groups, however, individual, disaggregated voters are plagued with rational ignorance problems that make it irrational for them to expend the resources necessary to obtain information about the details of the political process as it relates to a wide range of issues. While members of shadow interest groups find it irrational to become informed about most issues, they do find it in their interests to become informed about a certain issue or subset of issues.

\section{Commitment to Political Parties as a Substitute for COMMITMENT TO IDEOLOGY}

As discussed above, political parties do not serve the interests of disaggregated voters by notifying them of the ideological positions held by candidates. ${ }^{75}$ Instead, party labels serve the interests of shadow interest groups by providing them with low cost information about whether a particular candidate is electable. In this context the label theory seems to make sense.

As for the umbrella theory, ${ }^{76}$ it is not coincidental that political parties appear to serve as a banner for a variety of unrelated interest group constituencies. The political parties serve as intermediaries between interest groups and politicians for a variety of shadow interest groups. As intermediaries, the political parties are not concerned that

74. T. LOWI \& B. GINSBERG, supra note 65 , at 499 . The point being made here should not be confused with the argument made above against the "umbrella" theory. See supra text accompanying notes 56-58. The groups described by Lowi and Ginsberg are shadow interest groups. By contrast, the umbrella theory predicts that existing, well organized interest groups will identify with political parties. But, as pointed out above, well organized groups, unlike shadow groups, do not need political parties to serve as brokers between themselves and politicians. See supra text accompanying notes $57-58$.

75. See supra text accompanying notes 53-55; see also T. Lowi \& B. GINSBERG, supra note 65 , at 499 ("Even in the late 1960 s when American society was unusually polarized, the Democratic and Republican candidates stood for about the same things.").

76. See supra notes $56-58$ and accompanying text. 
the set of issues they support does not reflect a consistent ideological pattern.

For politicians, therefore, party loyalty serves as a substitute for ideological commitment. Because current voters typically cannot actually bind the politicians for whom they vote to particular courses of action, problems of enforcement inevitably arise. A reputation for ideological commitment to certain positions "serves the same function in political exchange that brand-name capital serves in market transactions."77 A corollary is that political competition inevitably imparts an ideological tenor to campaigning as each candidate attempts to convince the voters that he is personally committed to a particular set of voters. ${ }^{78}$ Formal interest groups are likely to support candidates for public office who have a strong ideological commitment that coincides with the preferences of the interest group. The politicians' ideological commitment is a form of self-bonding that makes it less likely that the politician will deviate from the position to which he has precommitted on the basis of his ideology. ${ }^{79}$

Nevertheless, commitment to a particular ideology is costly because it requires a measure of consistency, forcing politicians to embrace positions that are costly in the near term. Thus the issue is whether the cost of opportunism, which comes in the form of lower credibility with political supporters, is worth the benefits, which come in the form of promised political support from the profiting groups.

A different precommitment strategy for politicians is to develop a reputation for party loyalty rather than for ideological commitment. The very high rates at which certain members of both parties vote with the party majority indicates that for at least some politicians the benefits of developing a reputation for party loyalty outweigh the costs. ${ }^{80}$ Yet, like ideological voting, party loyalty is costly. To maintain a reputation for party loyalty, a politician must vote with her party even when she would obtain short term benefits from deviating from the party line.

A strategy of committing to follow the majority position of a particular party serves as a substitute for ideological commitment. A particular politician must decide whether the net benefits from a strategy

77. Dougan \& Munger, The Rationality of Ideology, 32 J.L. \& EcoN. 119, 125 (1989).

78. Id. at $120-30$.

79. Id.

80. See Congressional Quarterly, Inc., Congressional Röll Call 1986, at 31-C. In the House of Representatives during 1986, 11 Democrats and 9 Republicans voted with their party majority and against the majority of the other party in at least $93 \%$ of the votes cast. In the Senate, 4 Democrats and 7 Republicans voted with their party majority at least $91 \%$ of the time. 
of party loyalty are greater than or less than the net benefits from a strategy of ideological commitment. In this context, the fact that the positions of the political parties on various issues are eclectic and incoherent, and do not reflect a consistent ideological pattern, is a virtue rather than a vice. The parties' lack of a consistent ideology allows politicians to make credible precommitments to shadow interest groups without being trapped into making politically costly commitments on side issues for the sake of proving ideological consistency.

Nevertheless, a reputation for loyalty to a political party is not a perfect substitute for a reputation for ideological commitment as a bonding device. Members of shadow interest groups are likely to believe that a commitment to a particular ideology is a more credible bond than a commitment to party, since the societal pressures against departing from one's ideology are higher than the societal pressures against deviating from the party line. Nonetheless, a reputation for commitment to a particular political party can be a powerful bonding device. A politician who has developed such a reputation often will find that the short term benefits from deviating from the party line will be lower than the long term costs, which come in the form of decreased credibility. Such decreased credibility means that both shadow interest groups and formal interest groups will be less willing to provide political support for a promise of future regulatory favors.

Not surprisingly, the politicians most likely to deviate from the positions taken by their own party are Southern Democrats and Northern Republicans. The cost of party loyalty to these politicians is very high since they represent districts in which a majority of voters embrace ideologies that place them in frequent opposition to the positions taken by their representatives' parties. ${ }^{81}$

The thesis that a reputation for strong political party affiliation is a substitute for a reputation for ideological commitment as an ex ante bonding strategy for politicians is empirically testable. If voters believe that ex post reneging by politicians is a problem, then the longer the term of office being contested, the bigger the problem is likely to be in the minds of voters. ${ }^{82}$ This implies that party affiliation should be more important in Senate races than in House races. The available evidence supports this result. Alan Abramovitz has found that "party identification had a greater impact on (voters') evaluations of Senate

81. Thus it is not surprising that six of the seven Senate Democrats who most consistently voted against their party majority in 1986 were from the South (the seventh was from Nebraska), while six of the seven Senate Republicans who most consistently voted against their party majority were from liberal states, i.e., Connecticut, Pennsylvania (two), North Dakota, and Oregon (two). Id.

82. Dougan \& Munger, supra note 77 , at 125. 
candidates than on (voters') evaluations of House candidates."83 Interestingly, while party affiliation was more important to voters in Senate races than in House races, party affiliation was a significant factor in voters' decisions about candidates for both chambers. ${ }^{84}$ Moreover, party identification was considered by voters to be more significant than ideological orientation in both the House and the Senate. ${ }^{85}$

\section{The Political Scientists' Normative Perspective}

My theory also casts doubt on the political scientists' view that political parties promote majority rule by "affording greater representation to diffuse majority sentiments," 86 and by generating a "countervailing collective power on behalf of the many individually powerless against the relatively few who are individually - or organizationally - powerful."87 Although political parties do not appear to promote civic virtue in government as some have claimed, they may nevertheless serve a useful function in a representative democracy.

Viewed from a pluralist rather than a republican perspective, political parties can serve as an important counterweight to organized interest groups. That is, to the extent that the preferences of the shadow interest groups affiliated with the political parties are opposed to the preferences of the formally organized interest groups, the ability of political parties to mobilize such shadow interest groups enables these groups to serve as countervailing forces to formal interest groups.

This will not always be the case. Like formally organized interest groups, politicians will search for issues that transfer wealth from diffuse voters to shadow interest groups. They will try to avoid issues that put shadow interest groups into direct conflict with formal interest groups because the costs associated with such outcomes will be high. In other words, political scientists and their followers are wrong to suggest that strong political parties will promote civic virtue and republicanism. Still, they may be correct in thinking that shadow in-

83. Abramovitz, A Comparison of Voting for U.S. Senator and Representative in 1978, at 74 AM. Pol. SCI. REv. 633 (1980).

84. See id. at 636 , Figure 1. The standardized regression coefficient for party identification was 0.148 for House candidates, and 0.263 for Senate candidates. Standardized regression coeffcients are used to facilitate comparisons between regression coefficients within a single equation. A standardized regression coefficient shows the change in the mean response as measured in units of standard deviations when all other independent variables are held constant. J. NETER \& W. WASSERMaN, APPLIEd LINEAR STATISTICAL MODELS: REgRESSION ANALYSIS OF VARIANCE, AND EXPERIMENTAL DESIGNS 278-68 (1974).

85. Id.

86. Fitts, supra note 32, at 1607.

87. W. Burnham, Critical Elections and the Mainsprings of American Politics 133 (1970). 
terest groups will serve as a check on organized interest groups. The meta-question is whether the ability of political parties to organize shadow interest groups is beneficial on balance. On the positive side of the equation is the ability of political parties and shadow interest groups to check formal interest groups. On the negative side is the ability of such groups to transfer wealth from the population as a whole to themselves. Thus, the question of whether the social benefits of political parties outweigh the social costs has no a priori answer. The question is empirical.

\section{CONCLUSION}

For some time now both political scientists and economists have been casting about for a useful explanation of the role of political parties in American political life. The existence of these parties does not fit easily into sophisticated, interest group dominated models of the political process. On the one hand, formal interest groups do not appear to need political parties because these groups already enjoy access to politicians. In addition, such groups can, at low cost, monitor and enforce the deals they strike with legislators. On the other hand, neither of the two major political parties appears to have any particular use for highly unorganized, disaggregated voters who are unable to supply political support in any meaningful way.

The role of the political parties seems clear, however, when shadow interest groups are introduced into the calculus. Shadow interest groups have the resources and the inclination to provide political support to politicians, but they need an intermediary to reduce the costs of monitoring the politicians with whom they deal. Political parties are uniquely suited to meet the needs of these groups. The parties recruit and screen potential candidates, inform them about the preferences of shadow interest groups, and monitor and evaluate the performance of the candidates once they are elected. The ability of political parties to perform these services gives shadow interest groups the ability to express themselves in the political process without subjecting themselves to the specter of rent extraction.

My theory of political parties casts doubt on the normative conclusions of political scientists who see the parties as an important mechanism for promoting majority rule in the United States. There is no particular reason to believe that the policy preferences of shadow interest groups are any broader or virtuous than the views of formally organized interest groups. The only distinction between shadow interest groups and formal interest groups is in their respective choice of organizational form. On the other hand, the presence of a robust two- 
party system does promote the ability of certain factions to make themselves heard in the political process. In an age in which the power of well organized special interest groups seems to be continually on the rise, healthy political parties serve as a check on their activities by mobilizing shadow interest groups to oppose them. 